\title{
The Ideology of the Perfect Dictionary: How Efficient Can a Dictionary Be?
}

Michaël Abecassis, Department of Modern Languages, University of Oxford, Oxford, United Kingdom (michael.abecassis@mod-langs.oxford.ac.uk)

\begin{abstract}
Dictionaries have become essential tools of the modern world. Not only have dictionary sales dramatically increased, but the variety of dictionaries and the competition between editors are also very much on the rise. Monolingual dictionaries attract native speakers for several reasons. Some wish to capture the subtleties of their own language, others to speak the 'standard' language, and an 'ideologically' politically correct variety devoid of colloquialisms, hence the crucial role played by style labels. Furthermore, a large number of word enthusiasts enjoy linguistic curiosities, archaisms and other vestiges from the past conserved in dictionaries. Is the concept of a perfect dictionary a reality or an ideal? There is no perfect student. Language learners, for whom dictionaries are of great importance, seek user-friendly material which will improve both their fluency in and understanding of the target language, and embed acquired lexis in their long-term memory. Lexicographers, in their search for perfection and in compliance with users' wishes, are constantly innovating, and every dictionary hopes to become a landmark in lexicography and in second language acquisition. This article aims to look at the way dictionaries have evolved and assess the latest generation of computer-based dictionaries, as well as consider possible developments which will contribute to the compilation of future dictionaries.
\end{abstract}

Keywords: LEXICOGRAPHY, LEXICAL ACQUISITION, VOCABULARY, STYLE LABELS, CORPUS/CORPORA, DICTIONARIES, IDEOLOGY, STANDARD, LANGUAGE LEARNING, FRENCH MONOLINGUAL DICTIONARIES, ELECTRONIC DICTIONARIES, CD-ROMS

Opsomming: Die ideologie van die volmaakte woordeboek: Hoe doeltreffend kan 'n woordeboek wees? Woordeboeke het noodsaaklike werktuie van die moderne wêreld geword. Nie alleen het woordeboekverkope dramaties vermeerder nie, maar die verskeidenheid woordeboeke en die wedywering tussen redakteurs is ook aansienlik aan die toeneem. Eentalige woordeboeke trek moedertaalsprekers om verskeie redes aan. Sommige wil die subtiliteite van hul eie taal bemeester, ander wil die "standaard"-taal en 'n "ideologies" polities korrekte variëteit sonder gemeensame uitdrukkings praat, vandaar die uiters belangrike rol wat styletikette speel. Daarbenewens hou 'n groot aantal woordentoesiaste van taaleiesoortighede, argaïsmes en ander oorblyfsels uit die verlede wat in woordeboeke bewaar word. Is die konsep van 'n volmaakte woordeboek ' $n$ realiteit of ' $n$ ideaal? Daar is geen volmaakte student nie. Taalaanleerders vir wie woordeboeke van groot belang is, soek gebruikersvriendelike gegewens wat sowel hul vlotheid in as hul verstaan van die doeltaal sal verbeter, en aangeleerde leksis in hul langtermyngeheue vaslê. Leksikograwe, in hul soeke na volmaaktheid en ooreenkomstig gebruikers se wense, is voortdurend besig om te vernuwe en elke woordeboek hoop om 'n baken in die leksikografie en tweedetaalverwerwing te word. Hierdie artikel wil kyk na die manier waarop woordeboeke ontwikkel het en die jongste generasie rekenaargebaseerde woordeboeke beoordeel sowel as moontlike ontwikkelinge beskou wat sal bydra tot die samestelling van toekomstige woordeboeke. 
Sleutelwoorde: LEKSIKOGRAFIE, LEKSIKALE VERWERWING, WOORDESKAT, STYLETIKETTE, KORPUS/KORPUSSE, WOORDEBOEKE, IDEOLOGIE, STANDAARD, TAALAANLERING, FRANSE EENTALIGE WOORDEBOEKE, ELEKTRONIESE WOORDEBOEKE, CDROMS

Dictionaries are commonly regarded as authoritative reference books which establish the standardness of the language, the appropriate spelling, the definition, the register or the grammatical status of a particular lexical item. They have become an essential part of people's lives with thousands being sold every year throughout the world. The concept of a standard language is in itself a subjective evaluation: it represents 'an idea in the mind rather than a reality a set of abstract norms to which actual usage may conform to a greater or lesser extent' (Milroy and Milroy 1992: 23). 'Standard' therefore refers to the long-established codified variety, promoted by education, grammar books, text-books and dictionaries, that establish what is 'correct' and proscribe what should not be said or written. Such a system of attitudes to linguistic variation has been labelled the 'ideology of the standard' (Milroy and Milroy 1992: 23). The attitude to lexicography has changed since the 1970s with dictionaries being increasingly descriptive rather than prescriptive. However, today's generalpurpose dictionaries and EFL learner's dictionaries, descriptive though they may be, still strongly emphasize the standard language (more non-standard words are included than in the past but categorized and style-labelled with a wide range of markers to account for socio-situational variation) and there may be speculated whether the image they reflect of language is accurate or purely ideological. Leech and Nesi (1999: 295) in their study of modern EFL dictionaries acknowledge the growing interest and advances in lexicography, but are forced to recognize that these dictionaries 'fall well short of perfection'. This article will concentrate mostly on EFL dictionaries, with a particular focus on French and English, and will gauge whether it is possible for lexicographers relying more and more on large-scale language corpora to give a true picture of the vitality of the language.

\section{The social and stylistic continuum: the example of French monolin- gual dictionaries}

The attitude of the speaker towards language is very complex and relies on 'fictive, prescriptive and evaluative norms' (Houdebine 1982: 50), based on extralinguistic factors which could be political, social, psychological or ideological. Although Quirk et al. (1985: 26) suggest a social and stylistic stratification of English into 'very formal-FORMAL-neutral-INFORMAL-very informal', the OALDCE lists fifteen different stylistic values that account for temporality, connotations and denotations attached to each entry. Webster's New Collegiate Dictionary (1976) classifies words as 'slang', 'nonstandard' and 'substandard', each style label defined by its relation to a standard or norm, whereas COBUILD 
favours the terminology 'formal', 'informal', and 'offensive' words. As Stein (2002: 14) notices 'it is admittedly very difficult to make objective assessments on the social status of words, but it seems [...] that we need much more research in this area'. There is a certain degree of inconsistency in the use of style labels in dictionaries. Imbs (1969: 51) sees the role of style labels as specifying 'des niveaux ou registres de langue, c'est-à-dire des connotations de nature sociale, culturelle ou affective' ('language levels or registers, that is to say social, cultural or affective connotations'). The divide between the prestige norm (codified usage) and non-standard items (colloquial usage) in the lexicon can be expressed in terms of high and low varieties (Lodge 1989: 427-428). All languages have a stock of high-value words reserved for formal contexts and lowvalue words for informal situations. It is the knowledge of these different styles that constitutes learners' fluency.

Wooldridge (1977), in his study of a nomenclature of early dictionaries, classifies the lexicon lemmatized in dictionaries in the way shown in Graph 1.

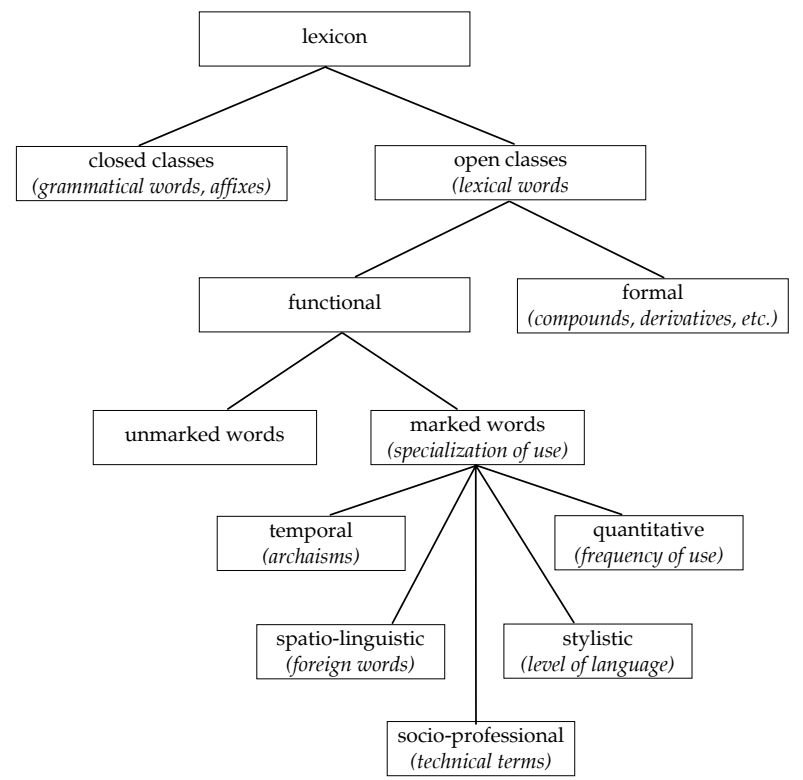

Graph 1: Nomenclature of word classes in a lexicon (adapted from Wooldridge 1977: 83 by Shaw 1997)

Low-status items, which had since the 17th century been regarded more as curiosities in France (Oudin 1640, Michel 1807), gave birth to numerous glossaries or dictionaries (Rigaud 1878, Caradec 1977, Merle 1986). They are now widely included in general dictionaries, being part of the linguistic repertoire of native speakers and often popularized by the media and a young generation willing to be subversive and politically incorrect. 
Graph 2 represents the conception of the stylistic continuum in modern French dictionaries, to which have been added the designations unlabelled and absent. Unlabelled items constitute the stylistically unmarked core of the lexicon. Absent words refer on the one hand to those words at the bottom of the stylistic continuum that lexicographers do not select for inclusion or on the other hand to those words belonging to the supernorm too specialized for a general dictionary. Three subgroups are distinguished by means of circles: the low variety, the core and the 'supernorm'. The core corresponds to the 'common language' (Meillet 1921). This graphic representation of style labels therefore intends to contrast the core and the low variety (usages that infringe the prescriptive norm) with the 'supernorm' (Müller 1985: 226), for which Garmadi (1981: 65) prefers the notion of the 'supra-norm'. The latter represents, in Garmadi's words, 'l'idéal esthétique ou socioculturel d'un milieu détenant prestige et autorité $[. .$.$] l'existence de ce système d'instructions implique celle d'usages$ prohibés' ('the aesthetic or sociocultural ideal of a milieu with prestige and authority [...] the existence of this system of instructions implies that of prohibited usages'). Müller uses the term 'supernorm' to refer to a variety outside the core, in other words 'educated French', a writing-like language variety used in upper-group speech or found in literature and formal writing. The 'supernorm' has prestige and authority within a profession or a social group. Meillet (1921: 115) speaks of 'langues spéciales' (special languages). The languages of administration or science, as technical but still prestigious language varieties, stand midway between the core and the 'supernorm'. The low variety and the 'supernorm' constitute, to use Rey's (1972: 17) formulation, 'un pseudo-système [qui] se donne pour le système' ('a pseudo-system that asserts itself as the system'). Both of them could enjoy covert prestige with a particular group or social class. However, the 'supernorm', unlike the low variety, is to some extent 'codifié' ('codified') and 'normalisé' ('normalized') (Garmadi 1981: 56-57).

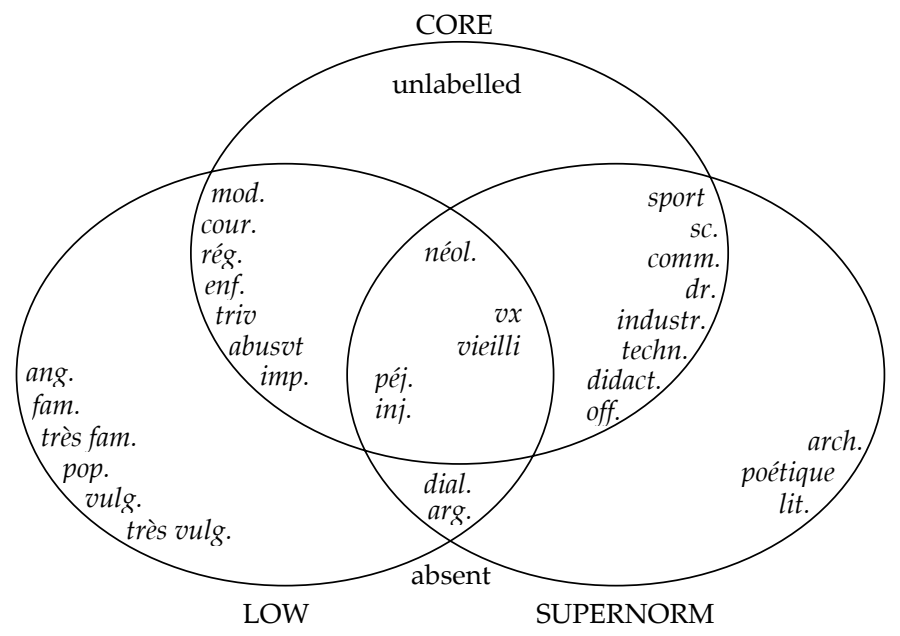

Graph 2: Some of the style labels in Le Nouveau Petit Robert (1993) 
Graph 2, classifying some of the style labels in Le Nouveau Petit Robert (1993), shows that the three subgroups may interrelate. The labels vieilli (outdated) and $v x$ (vieux, obsolete) can for example combine with fam. (familier, colloquial) or pop. (populaire, popular) as well as unlabelled or lit. (littéraire, literary) words. This is also the case with the label néol. (néologisme, neologism). Some unlabelled words can be rated as péj. (péjoratif, derogatory) or inj. (injurieux, offensive). Standard items can also have a derogatory or offensive connotation and receive the labels péj. or inj. Between the core and the low category, words are found labelled as mod. (moderne, currently used), cour. (courant, commonly used), rég. (régional, regional), enf. (enfantin, children's usage), triv. (trivial, coarse), absusvt (abusivement, abusively used) and imp. (impropre, incorrect). Purists consider Anglicisms, labelled ang. (anglicisme) in the low category, as non-standard forms. While some have merged into French, they are no longer labelled as Anglicisms. Items labelled vulg. (vulgaire, vulgar), on the contrary, belong to low usage. As Lodge points out, the label pop. 'with its very nebulous sociological rather than stylistic basis [...] seems particularly inappropriate' (1989: 442-443), especially on account of the fact that social classes in France are not clearly definable. It could be said that both fam. and pop. are stylistic rather than social indicators on the low/high continuum. The latter variety, being more informal than the first, can be placed between fam. and vulg. on the graph. There is much disparity in dictionaries, even in Le Petit Robert. For no particular reason, some labels appear abbreviated, some not. In their judging of the different degrees of familiarity, dictionaries use labels such as très fam. (very familiar) or très vulg. (very vulgar). The label arg. (argot, slang) has been placed overlapping the low variety and the 'supernorm'. Although some of its usages are still traditionally regarded as having low status (dead slang), the 'langues de spécialité' (specialist languages, living slangs) belong to the 'supernorm'. The label dial. (dialectal, dialectal) is rated as a form of regional slang. Technical vocabularies associated with a particular occupation (professional slangs) (labelled sport (sports), sc. (science, science), comm. (commercial, marketing), $d r$. (droit, law), industr. (industrie, industry), techn. (technique, technical), didact. (didactique, didactic), and off. (officiel, official) by Le Petit Robert) likewise overlap with both the 'supernorm' and the high variety, some of these items being commonly used in spontaneous French. The terminology used by dictionaries is arguable, as words labelled lit., poétique (poetical) and arch. (architecture, architecture) enjoy overt prestige, while all technical language varieties including slang have covert prestige among their users.

A comparison of Le Larousse du XXème siècle (1932) where only major style labels such as fam., pop. and arg. were used with the more recent Le Petit Larousse illustré (1989) and Le Nouveau Petit Robert (1993) shows that the differentiation between style labels has become increasingly subtle (Abecassis 2004). The appearance of cour. (courant, commonly used) and mod. (moderne, currently used) gives a diachronic dimension to the diatopic, diaphasic or diastratic variations. The label ang. (anglicisme, Anglicism) has a negative connotation in 
Le Robert but not in Le Larousse. Unlike Le Larousse, Le Robert uses a range of labels to refer to technical vocabularies (e.g. sport (sports), sc. (science, science), comm. (commercial, marketing), etc.).

As the differences between spoken and written forms become more blurred with the use of email and text messages, today's dictionaries aim at being more and more comprehensive with the inclusion of slang and technical jargons, as well as encyclopaedic knowledge. Rey's Dictionnaire culturel en langue française (2005) with more than 80000 quotations and 65000 entries presents words in their contexts with references to popular customs and beliefs and encapsulates a wide range of disciplines from mathematics to economics as well as music, history and psychology. Looking at monolingual dictionaries and their style labels made it possible to show how lexical entries are categorized, and the difficulty in finding consistent terminology that would encapsulate their lexicons. Nor is it possible for a dictionary to be exhaustive for practical reasons. Words are selected according to their usage, and archaisms tend to be omitted. In 2004 the French journalist Bernard Pivot, creator of the famous spelling championships, listed a hundred words which are threatened with becoming obsolete and which deserve to be saved by lexicographers. Dictionaries also have the function of preserving language usage which forms an integral part of a community's cultural heritage.

\section{Types of dictionaries}

If the Oxford English Dictionary excels as the English reference work par excellence, other types of dictionaries are used by learners of English. Second language learners tend to prefer bilingual dictionaries to monolingual ones as reference books (Martin 1998). However, bilingual dictionaries are often incompetently used with students only relying on a word-for-word translation or ignoring the whole range of translations a word can have. Monolingual dictionaries are often recommended by teachers of a second language, especially at the intermediate level, to encourage learners to think in the target language. Given the lack of research on this topic, it has been impossible to establish the superiority of monolingual dictionaries (Wingate 2002: 1). Not only are native speakers in search of a definition or the spelling of a word frequent users of general-purpose dictionaries, but language learners who are already proficient in the language and have a good grasp of the grammar and lexical basis, will also seek 'to extend their vocabulary into the more peripheral areas of the lexicon' (Leech and Nesi 1999: 300). Foreign language teaching generally focuses on the vitality of the language and tends to exclude obsolete forms ${ }^{1}$ which the speaker is unlikely to encounter or neologisms on account of their non-standard nature. Apart from monolingual and bilingual dictionaries, there are bilingualized dictionaries which combine the function of both bilingual and monolingual dictionaries: 'Whereas bilingual dictionaries usually provide just an L1 synonym, bilingualized dictionaries include L2 definitions, L2 sentence 
examples, as well as L1 synonyms. Bilingualized dictionaries were found to result in better comprehension of new words than either bilingual or monolingual dictionaries' (Hunt and Beglar 2005). The hybrid bilingualized learner's dictionary is a relatively new genre of dictionary which, although it has attracted some criticism, is thought to be suitable for all learners, whatever their proficiency, who prefer to rely on the source-language translation equivalents.

\subsection{Language learner's dictionaries and lexical acquisition}

The number of new editions of language learner's dictionaries released every year by Hachette, Oxford, Longman and Collins among others, mostly for English as a foreign language but also for French, German, Italian and Spanish, has increased over the past ten years, to the extent that it has been extremely difficult for learners to find the foreign language dictionary which will best suit their needs. There is no such thing as a perfect dictionary, just as there is no perfect language learner, and every user has different needs according to his / her culture, background, age or level. ${ }^{2}$ The major hindrance in using a dictionary is that the user often does not possess the necessary skills to utilize it efficiently (Hartmann and James 1998) or is insufficiently guided by the preface to exploit its possibilities. Most students in British universities not only lack the dictionary-using abilities and the look-up strategies required to fully exploit on their own the resources of an English learner's dictionary, but they also often prefer bilingual to monolingual dictionaries (Nesi 2000).

Cowie (2000) has described in detail the early history of EFL dictionaries and their evolution since the early 1980s thanks to the input of large-scale corpora of English, the British National Corpus and the Bank of English, ${ }^{3}$ and their improvement to meet the needs of users, by employing authentic language, in this way becoming more user-friendly. While Johnson's dictionary (1755) drew extensively on literary quotations (Krishnamurthy 2002), vast corpora which comprise literary texts, newspaper articles and informal natural speech have yielded a wide variety of genuine, up-to-date examples which carry greater authority and are particularly enlightening in establishing the state of a language at a particular time. The history of EFL dictionaries started remotely from Europe in Japan and India, where the three pioneers of EFL dictionaries, H.E. Palmer, A.S. Hornby and M.P. West, taught and conducted extensive research in L2 teaching on both Japanese and Indian EFL students. At a first stage, Palmer (1933) and later West and Endicott (1935) as well as Palmer and Hornby (1937) started elaborating word-lists which Cowie (1999) refers to as the 'structured lexicon', that part of the lexis which, in everyday conversation, is the most frequently used. By focusing on this core vocabulary and using particular arrangements (each entry would include its range of meanings and derivatives), they encouraged the user to encode. West and Endicott's New Method English Dictionary effected the innovation that the vocabulary used in the definitions of each lexical item was kept to the very simplest. It is thought that a minimum of 2000 words is necessary to understand a word definition in 
a second language (Nation 2001: 292). Dictionaries had in the past resorted to mere synonyms or used complex vocabulary in their definitions of particular items which was a major impediment to students. Also in his controlled vocabulary West included a list of some of the most frequent prefixes and suffixes which users might encounter, thus giving them the foundation for word construction.

The earlier EFL dictionaries, in the tradition of general dictionaries, were essentially prescriptive, drew quotations from literary sources and prescribed colloquial examples (Krishnamurthy 2002). From the 1970s, EFL dictionaries endeavoured to be more descriptive and innovative by using IPA transcriptions for pronunciation, descriptive definitions, usage notes on various aspects of the target culture, institutions and customs which in an often very entertaining way inform the user on a wide range of topics, though sometimes verging too much on social stereotypes or academic terminology, and, in the case of Longman, phrasal verbs, information on collocations and grammar patterns, with specifications for the syntactic use of words. In addition, numerous pictures and illustrations ${ }^{4}$ clarify abstruse meanings or technical vocabulary and definitions favour invented examples which contextualized lexical items in authentic quotations. Dictionaries are now increasingly supplemented by practical exercises with explanations and corrections. There are generally three types of dictionaries most specifically targeting language learners of English such as the series edited by Collins COBUILD (see Table 1): student's dictionaries, learner's dictionaries and advanced learner's dictionaries.

\begin{tabular}{|c|l|r|}
\hline \multicolumn{1}{|c|}{ Title } & Level targeted & Capacity \\
\hline $\begin{array}{c}\text { Collins COBUILD Advanced } \\
\text { Learner's Dictionary }\end{array}$ & Intermediate/ & 1167 pages \\
& Advanced & 75000 references \\
& & 105000 examples \\
\hline Collins COBUILD Concise & Intermediate & 1344 pages \\
Learner's Dictionary & & 60000 references \\
& & 55000 examples \\
\hline Collins COBUILD Student's & Intermediate & 1088 pages \\
Dictionary & & 200 pages of English \\
& & grammar \\
\hline
\end{tabular}

Table 1: Collins COBUILD Language Learner's Dictionaries

The less advanced the users targeted, the smaller the size of the lexicon and the fewer the references and examples, as can be seen when the statistics of the three Collins COBUILD dictionaries are compared. For a language learner's dictionary in contradistinction to any other English dictionary lexicographers have selected what constitutes the essential core of a language (Stein 2002: 35) and have opted in their definitions for full grammatical sentences with a simpler and more transparent vocabulary. Each definition shows grammatical patterns with additional sections on phrasal verbs and loan words, and word 
usages are illustrated by several examples. The third edition of the Collins COBUILD English Dictionary for Advanced Learners includes a practical guide to dictionary use, and has an extensive coverage of American English. Dictionaries often focus on British English and lack references to dialects and regional varieties. Little can be found on regional varieties of English such as that spoken in the West Indies, New Zealand or Australia, and this is an aspect that requires improvement (Leech and Nesi 1999: 300). Besides, as Stein (2002: 75) notes, the latest EFL dictionaries are biased in favouring Received Pronunciation (RP) over American English. Each new edition of a dictionary intends to innovate with a newly devised user-friendly layout which would guide learners more quickly to the word sought. Special labelling and use of colour highlight the most frequently used lexical items. Coverage of today's 'trendy' English such as the language of computing and telecommunication is emphasized, which makes the volume more exhaustive (the dictionary accounts for $90 \%$ of written and spoken language). In the MacMillan English Dictionary for Advanced Learners (2002), red stars are used to tag the most frequently used items which constitute the core of the English language.

Dictionaries in electronic form also require from the students a high degree of practice and a careful study of the help menu. Navigational and searching skills will become advanced once users have familiarized themselves with the software. Computerized English dictionaries can contain over a million lexical items and phrases and also include access to multiple search functions in other languages. With new developments in computerization, CDROMs, and electronic and pocket dictionaries have been released to supplement paper editions of dictionaries. The practicality of these materials immediately comes to mind. Compared to paper editions, they are easy to carry, light and cheap, and the search for words is often faster (Weschler 2000). The use of multimedia has proven to help vocabulary acquisition (Chapelle 2001), but as to whether words learnt electronically by students are in the long run better memorized needs to be further investigated by lexicographers. Since the searching process has been accelerated by e-dictionaries and therefore exposure to the words is shorter, it may be doubted that memorization is as efficient. CD-ROMs provide the user with a considerable number of multimedia possibilities that can be exploited (game-like audio and video support, interactive exercises with different levels to choose from, hypertext links and internet links). Some are equipped with spelling games, exercises, lists of synonyms, antonyms and thesauri. The pronunciation, intonation of isolated lexical items or full sentences can now be heard, which for language learners is an invaluable resource. In addition, the user can become acquainted with pragmatic features particular to the target language such as body language and other gestures. Corpora are now available on-line, which has given the opportunity for both teachers and students to have direct and easy access to authentic data. Furthermore, concordance software like Scott's WordSmith Tools makes it pos- 
sible for students and teachers alike to compile their own corpus and look for particular collocations or idioms.

The process of learning vocabulary and the problems children face in the learning process have been extensively studied by Siskind (1997); similarly the mental aspects of how the mind organizes and processes vocabulary has been investigated (Aitchison 1987). It could be agreed with Aarts (1999: 16) that ideal learner's dictionaries should perform two major roles: 'they should enable students to decode what they do not understand and, at the same time, serve as instruments that enable them to produce their own texts'. The dictionary is indeed an instrument in language learners' long process of building up their own lexicons and developing fluency in another language. As they come across new vocabulary, they also learn strategies, and reusing them in context will improve retention. Not using the acquired vocabulary or lack of practice in context, on the contrary, will inevitably lead to vocabulary loss. Since, for most language learners working in their country of origin, exposure to a natural speaking environment is missing, they must have recourse to dictionaries and written sources. Language acquisition may be intentional with 'the learner's deliberate decision to commit information to memory' (Laufer and Hulstijn 2001: 1) (explicit learning), or incidental with the learner broadening his/her vocabulary knowledge and developing fluency without being aware of it (implicit learning). Graph 3 extracted from Hunt and Beglar (2005) shows the framework of language acquisition.

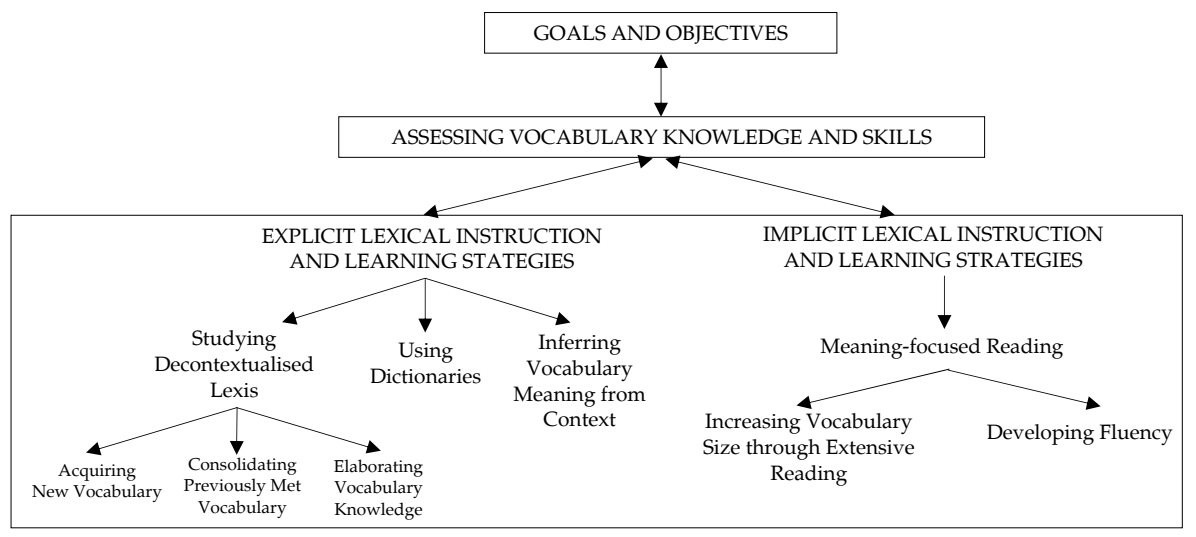

Graph 3: Framework for developing vocabulary knowledge and skills

(Hunt and Beglar 2005)

As shown in this graph, the use of dictionaries plays an essential part in lexical acquisition, with the studying of decontextualized lexis and the inferring of meaning from the context. When engaging in extensive reading, the EFL learner comes across words that he/she has learnt in context, and, with implicit exposure to idioms, collocations, discourse markers and syntactic structures, integrates them gradually into long-term memory. Much progress has been 
achieved by dictionary makers to improve on the presentation of lexical items and give 'today's user of English unrivalled access to the English they need' (CIDE). Comparing different learner's dictionaries to assess their suitability, such as statistically quantifying their coverage of verb, adjective and noun patterns, Klotz (1999: 42) has shown that one was not 'clearly better than the others', but that all four dictionaries he studied (CIDE, COBUILD2, LDOCE3 and OALD5) gave more emphasis to verb patterns and accorded less detail to the treatment of adjective and noun patterns. Most researchers agree that the learner's dictionary of today bears no comparison with previous ones because of the considerable input of corpus linguistics, but that there is still much to be done to improve its content and accessibility and that more research on its appropriateness is required. Dictionary makers, in their quest for the perfect learning instrument, both easy to understand and to use, keep on improving by benefiting from lexicographers' constructive remarks and learners' expectations and motivations, but the dictionary is only one part of lexical acquisition and is very much dependent on other external factors such as the learners' abilities, their age, background and the learning environment.

The learner's dictionary of the future will always strive to be more comprehensive and more attractive to the user and, complying with the desiderata of lexicographers, teachers and students alike, will endeavour to present information in a pedagogic, clear and challenging way, whilst relying on authentic material. Will electronic monolingual and bilingual dictionaries whose unlimited potential can link up not only with other on-line dictionaries but also with computer tools, spell checkers and thesauri ever supplant printed dictionaries? Though users will agree that their speed is convenient, it has not been shown yet whether this new generation of dictionaries substantially improves language learners' acquisition of native-like competence and knowledge, and broadens, in the long run, their lexicon. As there is a whole range of levels from beginners to advanced learners who work more independently, and as there are different learners in different teaching environments, it is likely that a proposed model of dictionary effectiveness is to a large extent subjective and, if left to the learners' judgement, what suits the needs of one user might be felt inappropriate for another. Future contributions on this subject will make it possible to evaluate the effectiveness of e-dictionaries and answer the question of whether the theory of a perfect dictionary is not mainly ideological.

\section{Endnotes}

1. See Stein (2002: 216-229) for the treatment of archaisms by EFL dictionaries.

2. A large number of studies have been conducted on the users of dictionaries (cf., for example, Dolezal and McCreary 1999, Bogaards 2003).

3. The Bank of English which is used for Collins COBUILD editions now contains over 320 million words.

4. The inclusion of illustrations is not something new. Already in the sixteenth century, Thomas 
Elyot's Dictionary (1538) was the first printed English dictionary to include illustrations, followed by Richard Huloet (1552), Thomas Cooper (1565), John Bullokar (1612) and Thomas Blount's illustrated word list in Glossographia (1656) (see Stein 2002: 172-173).

\section{Bibliography}

Aarts, F. 1999. Syntactic Information in OALD5, LDOCE3, COBUILD2 and CIDE. Herbst, T. and K. Popp (Eds.). 1999: 15-32.

Abecassis, M. 2004. Analyse diachronique du vocabulaire familier des films des années 30. French Studies in Southern Africa 33: 1-17.

Aitchison, J. 1987. Words in the Mind. Oxford: Blackwell.

Bogaards, P. 2003. Uses and Users of Dictionaries. Van Sterkenburg, P. (Ed.). 2003. A Practical Guide to Lexicography: 26-30. Amsterdam/Philadelphia: John Benjamins.

Caradec, F. 1977. Dictionnaire du français argotique et populaire. Paris: Larousse.

Chapelle, C.A. 2001. Teaching English as a Second or Foreign Language. Boston: Heinle and Heinle.

CIDE: Cambridge International Dictionary of English. (Edited by P. Procter.) 1995. Cambridge: Cambridge University Press.

COBUILD: Collins COBUILD English Dictionary for Advanced Learners. (Edited by J. Sinclair 1987, 1995.) Sixth Revised Edition with CD-ROM. 2006. Glasgow: HarperCollins.

COBUILD2: Collins COBUILD English Dictionary. (Edited by J. Sinclair.) Second Edition. 1995. London: HarperCollins.

Cowie, A.P. 1999. English Dictionaries for Foreign Learners: A History. Oxford: Clarendon Press.

Cowie, A.P. 2000. The EFL Dictionary Pioneers and their Legacies [online]. Kernerman Dictionary News 8. http://kdictionaries.com/newsletter/kdn8-1.html.

Dolezal, F.T. and D.R. McCreary. 1999. Pedagogical Lexicography Today: A Critical Bibliography on Learners' Dictionaries with Special Emphasis on Language Learners and Dictionary Users. Lexicographica. Series Maior 96. Tübingen: Max Niemeyer.

Garmadi, J. 1981. La sociolinguistique. Paris: Presses Universitaires de France.

Hartmann, R.R.K. and G. James. 1998. Dictionary of Lexicography. London/New York: Routledge.

Herbst T. and K. Popp (Eds.). 1999. The Perfect Learners' Dictionary (?). Lexicographica. Series Maior 95. Tübingen: Max Niemeyer.

Houdebine, A.-M. 1982. Norme et imaginaire linguistique. Le français moderne 50: 42-51.

Hunt, A. and D. Beglar. 2005. A Framework for Developing EFL Reading Vocabulary [online]. Reading in a Foreign Language 17(1). http:/ / nflrc.hawaii.edu/rfl/April2005/hunt/hunt.html.

Imbs, P. 1969. Les niveaux de langue dans le dictionnaire. Le français dans le monde 69: 51-60.

Johnson, S. 1755. A Dictionary of the English Language. London: Longman.

Klotz, M. 1999. Word Complementation in English Learners' Dictionaries - A Quantitative Study of CIDE, COBUILD2, LDOCE3 and OALD5. Herbst T. and K. Popp (Eds.). 1999: 33-43.

Krishnamurthy, R. 2002. The Corpus Revolution in EFL Dictionaries [online]. Kernerman Dictionary News 10. http://kdictionaries.com/newsletter/kdn10-9.html.

Laufer, B. and J. Hulstijn. 2001. Incidental Vocabulary Acquisition in a Second Language: The Construct of Task-induced Involvement. Applied Linguistics 22: 1-26.

LDOCE3: Longman Dictionary of Contemporary English. (Edited by D. Summers.) Third Edition. 1995. Harlow: Longman. 
Leech, G. and H. Nesi. 1999. Moving Towards Perfection: The Learners' (Electronic) Dictionary of the Future. Herbst, T. and K. Popp (Eds.). 1999: 295-306.

Le Larousse du XXème siècle. 1932. Paris: Larousse.

Le Nouveau Petit Robert. 1993. Paris: Le Robert.

Le Petit Larousse illustré. 1989. Paris: Larousse.

Lodge, R.A. 1989. Speaker's Perception of Non-standard Vocabulary in French. Zeitschrift für Romanische Philologie 105 (5-6): 427-44.

Macmillan English Dictionary for Advanced Learners. (Edited by M. Rundell and G. Fox.) 2002. London: Macmillan.

Martin, R. 1998. One Benefit of Monolingual Dictionaries in the Writing Classroom [online]. The Internet TESL Journal 4(10). http://iteslj.org/Articles/Martin-Dictionaries.html.

Merle, P. 1986. Dictionnaire du français branché. Paris: Le Seuil.

Michel, J.-F. 1807. Dictionnaire des expressions vicieuses usitées dans un grand nombre de départements et notamment dans la ci-devant Lorraine. Paris: Bentoux.

Milroy, J. and L. Milroy. 1992. Authority in Language: Investigating Language Prescription and Standardisation. London/New York: Routledge.

Müller, B. 1985. Le Français d'aujourd'hui. Paris: Klincksieck.

Nation, I.S.P. 2001. Learning Vocabulary in Another Language. Cambridge: Cambridge University Press.

Nesi, H. 2000. The Use and Abuse of EFL Dictionaries: How Learners of English as a Foreign Language Read and Interpret Dictionary Entries. Lexicographica. Series Maior 98. Tübingen: Max Niemeyer.

OALD5: Oxford Advanced Learner's Dictionary. (Edited by J. Crowther.) Fifth Edition. 2005. Oxford: Oxford University Press.

OALDCE: Oxford Advanced Learner's Dictionary of Current English. (Edited by S. Wehmeier and A.S. Hornby.) Seventh Edition with CD-ROM. 2005. Oxford: Oxford University Press. http:// www.oup.com/elt/catalogue/teachersites/oald7/?cc=gb.

Oxford English Dictionary. (Edited by J.A.H. Murray.) 1884-1933, 1933. Oxford: Oxford University Press.

Oudin, A. 1640. Curiositez françoises. Paris: A. de Sommaville.

Palmer, H.E. 1933. Second Interim Report on English Collocations. Tokyo: Kaitakusha.

Palmer, H.E. and A.S. Hornby. 1937. Thousand-Word English. London: George Harrap.

Pivot, B. 2004. 100 mots à sauver. Paris: Albin Michel.

Quirk, R., S. Greenbaum, G. Leech and J. Svartvik. 1985. A Comprehensive Grammar of the English Language. London/New York: Longman.

Rey, A. 1972. Usages, jugements et prescriptions linguistiques. Langue français 16: 4-28.

Rey, A. 2005. Dictionnaire culturel en langue française. Paris: Le Robert.

Rigaud, L. 1878. Dictionnaire du jargon parisien. Paris: P. Ollendorf.

Scott, M. 2004. WordSmith Tools. Version 4. Oxford: Oxford University Press.

Shaw, J. 1997. Contributions to a Study of the Printed Dictionary in France before 1539 [online]. http:// www.chass.utoronto.ca/ wulfric/edicta/shaw/frame.htm.

Siskind, J. 1997. A Computation Study of Cross-situational Techniques. Brent. M.R. (Ed.). 1997. Computational Approaches to Language Acquisition: 39-93. Amsterdam: Elsevier Science Publisher. 
Stein, G. 2002. Better Words: Evaluating EFL Dictionaries. Exeter: University of Exeter Press.

Webster's New Collegiate Dictionary. (Edited by H.B. Woolf.). 1976. Springfield MA: Merriam.

Weschler, R. and C. Pitts. 2000. An Experiment Using Electronic Dictionaries with EFL Students [online]. The Internet TESL Journal 6(8). http://iteslj.org/Articles/Weschler-ElectroDict.html.

West, M.P. and J.G. Endicott. 1935. The New Method English Dictionary. London: Longmans, Green.

Wingate, U. 2002. The Effectiveness of Different Learner Dictionaries: An Investigation into the Use of Dictionaries for Reading Comprehension by Intermediate Learner of German. Lexicographica. Series Maior 112. Tübingen: Max Niemeyer.

Wooldridge, T.R. 1977. Les débuts de la lexicographie française. Estienne, Nicot et le Thresor de la langue françoyse (1606). Toronto: University of Toronto Press. 